\title{
An Analysis of the Speaking Anxiety of Turkish Teacher Candidates
}

\author{
Kürşad Çağrı Bozkirli \\ Correspondence: Kürşad Çağrı Bozkırlı, Faculty of Education, Kafkas University, Kars, Turkey.
}

Received: February 14, 2019

doi:10.11114/jets.v7i4.4060

\author{
Accepted: March 4, 2019 \\ Online Published: March 11, 2019 \\ URL: https://doi.org/10.11114/jets.v7i4.4060
}

\begin{abstract}
The aim of this study is to analyse the speaking anxiety of Turkish teacher candidates studying in Kafkas University. The sample group of the research designed in the survey model consists of 181 Turkish teacher candidates studying in Kafkas University Faculty of Education in fall term of the 2018-2019 Academic Year, who are selected by the random sampling method. The "Speaking Anxiety Scale for the Teacher Candidates" consisting of three sub-dimensions, namely the "physiological symptoms", "skill-related anxiety" and "psychological state" and 40 items developed by Kinay and Ozkan (2014) has been used in the study as the data collection tool. The findings of the study where the SPSS 17.0 software package is used for data analysis have revealed that; while the speaking anxiety levels of Turkish teacher candidates are not high and do not change depending on their gender or their willingness to become a teacher, they change significantly depending on their grade and public speaking experience.
\end{abstract}

Keywords: speaking anxiety, Turkish teacher candidate, survey study

\section{Introduction}

Speaking is defined as "explaining one's thoughts using the words of a language" (Turkish Language Association [TDK], 2011). Speaking, which is acquired during babyhood, is a language skill used frequently by humans in terms of expressing themselves (Temizyurek, Erdem and Temizkan, 2017; Demir and Melanlioglu, 2014). Speaking skill is also the most significant characteristic distinguishing human beings from animals (Ozdemir, 2008; Kurudayioglu, 2014).

Despite the ever-increasing diversification of the means of communication, the speaking skill still has impact on the position of the person in social and public contexts, such as his/her milieu of family, friends and business, just as in the past. In this respect, not only what you say, but also how you say it, is important. As you reflect your personality when speaking, both the information you give during your business or education-related meetings and the way you deliver such information, i.e. your speaking skill are taken into account.

Although human beings come to life with a natural speaking skill, this skill needs to be developed by means of education so that it can be used in an appropriate and effective manner (Ucgun, 2007; Sever, Kaya and Aslan, 2008; Aktas and Gunduz, 2014). Since the preschool times, the basic goal of language education has been to help people learn the rules of the language and be able to express themselves. In the curriculum of Turkish Lesson, basic goals of language education are specified as follows: "to develop the listening/watching, speaking, reading and writing skills of students", "to help the students use Turkish language in a conscious, proper and careful manner in line with the rules of speaking and writing" and "to help the students express their thoughts, views, feelings and arguments orally and in writing in an effective and explicit manner" (Ministry of National Education [MEB], 2018). According to Gunes (2007, p. 97), the main objectives of speaking education are as follows: "1. To develop language skills, 2 . To develop communication skills, 3. To develop learning and comprehension skills, 4. To develop mental skills, 5. To develop social skills and 6. To develop mental independence skills".

A person may have speaking defects throughout the long education period and even after this period. These are: "a. Stress, intonation, rhythm or pausing defects, b. Use of the local dialect, c. Phonation defects, d. Poor vocabulary knowledge, e. Use of unnecessary body language during speaking" (Ucgun, 2007, p. 62). A person's ineffective use of the speaking skill may be arising from speaking defects or from the anxiety the person feels particularly when talking before a small or large group of people.

In general, anxiety is defined as the uneasiness or fear felt for no reason (Seyyar, 2017), which is a common problem mostly causing harm to people (Parker, 2002). Speaking anxiety is one of the psychological barriers hindering one from speaking in an effective way (Addison et. al., 2003). In this type of anxiety, advanced level of which is called as the 
"Public Anxiety Disorder" (Harris, Kemmerling and North, 2002; DSM V, 2014), the person may have mental and physical troubles particularly when talking before the public (Daly, Vangelisti and Lawrence, 1989). High anxiety may lead to mental and physical problems such as losing one's train of thought, persistent drying of throat, uneasiness and shaking in hands and arms (Demir and Melanlioglu, 2014; Sevim and Gedik, 2014).

Accurate and effective use of the speaking skill is a trait of a teacher, particularly a language teacher by nature. So in order to be a good teacher, one needs a language free from speaking defects and a psychological state free from factors such as anxiety, which would have a negative impact on speaking. Therefore, research on speaking defects and speaking anxieties of particularly Turkish teacher candidates is deemed to be significant considering the fact that they will become language teachers. Literature review revealed research on speaking anxieties of teacher candidates from different branches (Ozkan and Kinay, 2015; Deringol, 2018; Kuru, 2018) as well as Turkish teacher candidates (Kardas, 2015; Iscan and Karagoz, 2016; Ozdemir, 2018; Hasirci, 2018). On the other hand, both the diversity of the variables analysed for their impact on speaking anxiety and the diversity of the features of the teacher candidates studying in different universities are considered to be requiring further research in different universities with different variables. Therefore, it is believed that; a research on speaking anxieties of the Turkish teacher candidates studying in Kafkas University, which has no previous research on the subject, will contribute to the field. This research, which aims to analyse the speaking anxieties of the Turkish teacher candidates studying in Kafkas University, seeks to find answers to the following questions:

- What is the level of speaking anxiety in Turkish teacher candidates?

- Does the level of speaking anxiety change depending on the gender of Turkish teacher candidates?

- Does the level of speaking anxiety change depending on the grades of Turkish teacher candidates?

- Does the level of speaking anxiety change depending on the public speaking experience of Turkish teacher candidates?

- Does the level of speaking anxiety change depending on the willingness of Turkish teacher candidates in their choice of profession?

\section{Method}

\subsection{Research Model}

The research is carried out in descriptive survey model. Descriptive survey studies intend to describe certain events and phenomena and their reflections on the society (Forza, 2002).

\subsection{Sample Group}

Personal features of the Turkish teacher candidates participating in the research are as displayed in Table 1: The sample group of the research, which is designed in the survey model, consists of 181 Turkish teacher candidates studying in Kafkas University Faculty of Education in fall term of the 2018-2019 academic year, which are selected by the random sampling method. In random sampling method, "samples are randomly selected among the items to represent the whole mass" (Serper, Aytac and Bayram, 2013, p. 17).

Table 1. Personal features of the participants

\begin{tabular}{lllll}
\hline Personal Features & & $\mathrm{f}$ & $\%$ & Total \\
\hline \multirow{3}{*}{ Gender } & Female & 97 & 53.6 & \\
& & & & 181 \\
& Male & 84 & 46.4 & \\
& 1 & 63 & 34.8 & \\
Grade & 2 & 33 & 18.2 & 181 \\
& 3 & 52 & 28.7 & \\
\hline
\end{tabular}

According to Table 1, 97 of the participants are male (53.6\%) and 84 of them are female (46.4\%). 63 of the participants are studying in Grade 1 (34.8\%), 33 of them are studying in Grade 2 (17.9\%), 54 of them are studying in Grade 3 (29.3\%) and 33 of them are studying in Grade 4.

\subsection{Data Collection Tool}

The "Speaking Anxiety Scale for Teacher Candidates" developed by Kinay and Ozkan (2014) is used in the research as 
the data collection tool. The scale consists of three sub-dimensions, namely the "physiological symptoms", "skill-related anxiety" and "psychological state" and 40 items. The Cronbach Alpha reliability coefficients calculated by the developers of the scale for the sub-dimensions of "physiological symptoms", "skill-related anxiety" and "psychological state" are $.92, .83$ and .78 , respectively and it is .94 for the scale in general. The Cronbach Alpha reliability coefficients calculated for the sub-dimensions in this research are $.90, .84$ and .83 , respectively and it is .96 for the scale in general.

\subsection{Data Analysis}

The SPSS 17.0 package software is used in the analysis of the data collected in research. As the Kolmogorov-Smirnov test performed to determine whether the data is homogenous or not, has revealed a normal distribution, parametric tests have been used in data analysis. Accordingly, descriptive statistics is used to determine the speaking anxiety levels of Turkish teacher candidates; the Independent Samples T-test is used to determine whether the level of speaking anxiety changes depending on gender, public speaking experience and their willingness to become a teacher and the One-Way ANOVA analysis is used to determine whether it changes depending on their grade at school.

\section{Findings}

\subsection{Speaking Anxiety Levels of the Turkish Teacher Candidates}

Table 2. Speaking anxiety average scores of the participants

\begin{tabular}{cccc}
\hline Scale Dimensions & $\mathrm{N}$ & $\overline{\mathbf{X}}$ & $\mathrm{S}$ \\
\hline Physiological symptoms & 181 & 26.21 & 9.30 \\
\hline Skill-related anxiety & 181 & 15.93 & 5.12 \\
\hline Psychological state & 181 & 54.77 & 18.42 \\
\hline Scale Total & 181 & 96.93 & 30.25
\end{tabular}

According to Table 2, average score of the Turkish teacher candidates participating in study is 26.21 in the sub-dimension of "physiological symptoms", 15.93 in the sub-dimension of "skill-related anxiety", 54.77 in the sub-dimension of "psychological state" and 96.93 for the scale in general. The minimum score to be acquired in scale's "physiological symptoms" sub-dimension consisting of 11 items is 11 and the maximum score is 55; the minimum score to be acquired in scale's "skill-related anxiety" sub-dimension consisting of six items is 6 and the maximum score is 30 ; the minimum score to be acquired in scale's "psychological state" sub-dimension consisting of 23 items is 23 and the maximum score is 115 and the minimum score to be acquired from the scale in general is 40 and the maximum score is 200. Consequently it can be stated that Turkish teacher candidates do not have a high level speaking anxiety.

\subsection{Speaking Anxiety Levels of Turkish Teacher Candidates Depending on Gender}

Table 3. T-test results regarding the speaking anxiety levels of the participants depending on gender

\begin{tabular}{|c|c|c|c|c|c|c|c|}
\hline & Gender & $\mathrm{N}$ & $\overline{\mathbf{X}}$ & $\mathrm{Sd}$ & $\mathrm{t}$ & $\mathrm{df}$ & $\mathrm{p}$ \\
\hline \multirow{2}{*}{$\begin{array}{l}\text { Physiological } \\
\text { symptoms }\end{array}$} & Female & 97 & 26.81 & 9.35 & \multirow{2}{*}{.935} & \multirow{2}{*}{179} & \multirow{2}{*}{.351} \\
\hline & Male & 84 & 25.52 & 9.26 & & & \\
\hline \multirow{2}{*}{$\begin{array}{l}\text { Skill-related } \\
\text { anxiety }\end{array}$} & Female & 97 & 15.91 & 5.20 & \multirow{2}{*}{-.062} & \multirow{2}{*}{179} & \multirow{2}{*}{.950} \\
\hline & Male & 84 & 15.96 & 5.05 & & & \\
\hline \multirow{2}{*}{$\begin{array}{c}\text { Psychological } \\
\text { state }\end{array}$} & Female & 97 & 55.40 & 18.18 & \multirow{2}{*}{.491} & \multirow{2}{*}{179} & \multirow{2}{*}{.624} \\
\hline & Male & 84 & 54.05 & 18.76 & & & \\
\hline \multirow{2}{*}{ Total } & Female & 97 & 98.14 & 30.43 & \multirow{2}{*}{.575} & \multirow{2}{*}{179} & \multirow{2}{*}{.566} \\
\hline & Male & 84 & 95.54 & 30.17 & & & \\
\hline
\end{tabular}

According to Table 3, the speaking anxiety levels of the Turkish teacher candidates do not significantly change with depending on gender ["physiological symptoms" $(\mathrm{t}=.935, \mathrm{p}>.05)$, "skill-related anxiety" ( $\mathrm{t}=-.062, \mathrm{p}>.05)$, "psychological state" $(\mathrm{t}=.491, \mathrm{p}>.05)$ total $(\mathrm{t}=.575, \mathrm{p}>.05)]$. Consequently it can be stated that gender has no significant impact on the speaking anxiety levels of Turkish teacher candidates. 


\subsection{Speaking Anxiety Levels of Turkish Teacher Candidates Depending on Their Grade}

Table 4. ANOVA test result regarding the anxiety levels of the participants depending on grade

\begin{tabular}{|c|c|c|c|c|c|c|c|}
\hline & $\begin{array}{l}\text { Source of } \\
\text { Variance }\end{array}$ & $\begin{array}{c}\text { Squares } \\
\text { Total }\end{array}$ & $\mathrm{df}$ & $\begin{array}{l}\text { Squares } \\
\text { Average }\end{array}$ & $\mathrm{F}$ & $\mathrm{p}$ & $\begin{array}{l}\text { Source of } \\
\text { Difference }\end{array}$ \\
\hline \multirow{3}{*}{$\begin{array}{l}\text { Physiological } \\
\text { symptoms }\end{array}$} & Between-groups & 1417.039 & 3 & \multirow{3}{*}{$\begin{array}{c}472.34 \\
80.09\end{array}$} & \multirow{3}{*}{5.89} & \multirow{3}{*}{$.001^{*}$} & \multirow[t]{3}{*}{$1-3,1-4$} \\
\hline & Within-group & 14176.80 & 177 & & & & \\
\hline & Total & 15593.84 & 180 & & & & \\
\hline \multirow{3}{*}{$\begin{array}{l}\text { Skill-related } \\
\text { anxiety }\end{array}$} & Between-groups & 371.09 & 3 & \multirow{3}{*}{$\begin{array}{l}123.69 \\
24.57\end{array}$} & \multirow[t]{3}{*}{5.03} & \multirow[t]{3}{*}{$.002^{*}$} & \multirow{3}{*}{$\begin{array}{c}1-2,1-3 \\
1-4\end{array}$} \\
\hline & Within-group & 4349.57 & 177 & & & & \\
\hline & Total & 4720.66 & 180 & & & & \\
\hline \multirow{3}{*}{$\begin{array}{c}\text { Psychological } \\
\text { state }\end{array}$} & Between-groups & 6815.01 & 3 & \multirow{3}{*}{$\begin{array}{r}2271.67 \\
306.62\end{array}$} & \multirow[t]{3}{*}{7.40} & \multirow[t]{3}{*}{$.000^{*}$} & \multirow[t]{3}{*}{$1-3,1-4$} \\
\hline & Within-group & 54272.39 & 177 & & & & \\
\hline & Total & 61087.40 & 180 & & & & \\
\hline \multirow{3}{*}{ Total } & Between-groups & 19262.97 & 3 & \multirow{3}{*}{$\begin{array}{c}6420.99 \\
822.26\end{array}$} & \multirow[t]{3}{*}{7.80} & \multirow[t]{3}{*}{$.000^{*}$} & \multirow{3}{*}{$\begin{array}{c}1-2,1-3 \\
1-4\end{array}$} \\
\hline & Within-group & 145540.07 & 177 & & & & \\
\hline & Total & 164803.04 & 180 & & & & \\
\hline
\end{tabular}

$(* \mathrm{p}<.0 \overline{5)}$

According to Table 4, speaking anxiety levels of Turkish teacher candidates significantly vary in all sub-dimensions and in total anxiety points depending on the grades of the students. Results of the Tukey HSD Test performed to identify the groups displaying difference have shown that: $1^{\text {st }}$ grader Turkish teacher candidates have significantly higher anxiety scores in the sub-dimension of "physiological symptoms" than the $2^{\text {nd }}$ or $3^{\text {rd }}$ graders; 1 st grader Turkish teacher candidates have significantly higher anxiety scores in the sub-dimension of "skill-related anxiety" than the $2^{\text {nd }}, 3^{\text {rd }}$ or $4^{\text {th }}$ graders; 1st grader Turkish teacher candidates have significantly higher anxiety scores in the sub-dimension of "psychological state" than the $3^{\text {rd }}$ or $4^{\text {th }}$ graders and $1^{\text {st }}$ grader Turkish teacher candidates have significantly higher anxiety scores throughout the scale than the $2^{\text {nd }}, 3^{\text {rd }}$ or $4^{\text {th }}$ graders.

\subsection{Speaking Anxiety Levels of Turkish Teacher Candidates Depending on Their Public Speaking Experience}

Table 5. T test result regarding the anxiety levels of the participants depending on their public speaking experience

\begin{tabular}{|c|c|c|c|c|c|c|c|}
\hline & Experience & $\mathrm{N}$ & $\overline{\mathbf{X}}$ & $\mathrm{Sd}$ & $\mathrm{t}$ & $\mathrm{df}$ & $\mathrm{p}$ \\
\hline \multirow{2}{*}{$\begin{array}{l}\text { Physiological } \\
\text { symptoms }\end{array}$} & Yes & 134 & 24.87 & 8.80 & \multirow{2}{*}{-3.357} & \multirow{2}{*}{179} & \multirow{2}{*}{$.001^{*}$} \\
\hline & No & 47 & 30.03 & 9.72 & & & \\
\hline \multirow{2}{*}{$\begin{array}{l}\text { Skill-related } \\
\text { anxiety }\end{array}$} & Yes & 134 & 15.05 & 4.90 & \multirow{2}{*}{-4.086} & \multirow{2}{*}{179} & \multirow{2}{*}{$.000^{*}$} \\
\hline & No & 47 & 18.45 & 4.92 & & & \\
\hline \multirow{2}{*}{$\begin{array}{c}\text { Psychological } \\
\text { state }\end{array}$} & Yes & 134 & 51.38 & 16.77 & \multirow{2}{*}{$-4,390$} & \multirow{2}{*}{179} & \multirow{2}{*}{$.000^{*}$} \\
\hline & No & 47 & 64.45 & 19.62 & & & \\
\hline \multirow{2}{*}{ Total } & Yes & 134 & 91.32 & 27.92 & \multirow{2}{*}{-4.427} & \multirow{2}{*}{179} & \multirow{2}{*}{$.000^{*}$} \\
\hline & No & 47 & 112.93 & 31.21 & & & \\
\hline
\end{tabular}

$(* \mathrm{p}<.05)$

According to Table 5, speaking anxiety levels of Turkish teacher candidates significantly vary in all sub-dimensions and in total anxiety scores depending on their public speaking experience. Accordingly, Turkish teacher candidates with no public speaking experience have a higher level of speaking anxiety than those with experience. 


\subsection{Speaking Anxiety Levels of Turkish Teacher Candidates Depending on Their Willingness in Their Choice of Profession}

Table 6. T test result regarding the speaking anxiety levels of the participants depending on their willingness in their choice of profession

\begin{tabular}{|c|c|c|c|c|c|c|c|}
\hline & Willingness & $\mathrm{N}$ & $\overline{\mathbf{X}}$ & $\mathrm{Sd}$ & $\mathrm{t}$ & $\mathrm{df}$ & $\mathrm{p}$ \\
\hline \multirow{2}{*}{$\begin{array}{l}\text { Physiological } \\
\text { symptoms }\end{array}$} & Yes & 139 & 26.31 & 9.55 & \multirow{2}{*}{.254} & \multirow{2}{*}{179} & \multirow{2}{*}{.799} \\
\hline & No & 42 & 25.89 & 8.52 & & & \\
\hline \multirow{2}{*}{$\begin{array}{l}\text { Skill-related } \\
\text { anxiety }\end{array}$} & Yes & 139 & 16.05 & 5.23 & \multirow{2}{*}{.563} & \multirow{2}{*}{179} & \multirow{2}{*}{.574} \\
\hline & No & 42 & 15.54 & 4.76 & & & \\
\hline \multirow{2}{*}{$\begin{array}{l}\text { Psychological } \\
\text { state }\end{array}$} & Yes & 139 & 54.60 & 18.24 & \multirow{2}{*}{-.224} & \multirow{2}{*}{179} & \multirow{2}{*}{.823} \\
\hline & No & 42 & 55.33 & 19.21 & & & \\
\hline \multirow{2}{*}{ Total } & Yes & 139 & 96.97 & 30.48 & \multirow{2}{*}{.037} & \multirow{2}{*}{179} & \multirow{2}{*}{.971} \\
\hline & No & 42 & 96.78 & 29.85 & & & \\
\hline
\end{tabular}

According to Table 6, there is no significant difference among the speaking anxiety levels of Turkish teacher candidates depending on their willingness in their choice of profession ["physiological symptoms" ( $\mathrm{t}=.254, \mathrm{p}>.05)$, "skill-related anxiety" $(\mathrm{t}=.563, \mathrm{p}>.05)$, "psychological state" $(\mathrm{t}=-.224, \mathrm{p}>.05)$, total $(\mathrm{t}=.037, \mathrm{p}>.05)]$. Accordingly, willingness of Turkish teacher candidates in their choice of profession has no significant impact on their speaking anxiety.

\section{Discussion and Conclusions}

In this study, Turkish teacher candidates studying in Kafkas University were studied with respect to their speaking anxiety levels and the effects of gender, grade, public speaking experience and willingness in their choice of the profession, on the speaking anxiety levels.

Speaking anxiety levels of the participants were discussed in the research at first. Analysis of the sub-dimensions and the scores obtained from the scale in general revealed that participants had speaking anxiety, though it was not at a high level. This research finding is consistent with the researches of Kardas (2015) and Ozdemir (2018). While in the study performed by Kardas (2015) Turkish teacher candidates were found to have a low level of speaking anxiety, the research performed by Ozdemir (2018) revealed a moderate level of speaking anxiety in Turkish teacher candidates. Unlike these studies, Iscan and Karagoz (2016) revealed a high level of speaking anxiety in Turkish teacher candidates. The absence of high level of speaking anxiety in Turkish teacher candidates may be resulting from their sense of high self-adequacy regarding speaking. Furthermore, Katranci (2014) and Baki (2018) stated that teacher candidates' sense of self-adequacy had a positive impact on their communication skills. Hence, it can be concluded that research participants have a sense of high self-adequacy regarding speaking helping the reduction of speaking anxiety.

The results of the study have revealed that gender or willingness in the choice of profession had no impact on the speaking anxiety levels of Turkish teacher candidates whereas speaking anxiety levels significantly changed depending on the grade of the students and their public speaking experience.

The gender-related result is consistent with the literature. Kardas (2015) also notes that gender has no significant effect on speaking anxiety levels of Turkish teacher candidates. The results of certain researches carried out on teacher candidates from different branches are consistent with the results of this research which is conducted with Turkish teacher candidates. Studies conducted by Ozkan and Kinay (2015) and Deringol (2018) revealed that gender had no impact on speaking anxieties of the teacher candidates. On the other hand, the study carried out by Kuru (2018) highlighted that gender significantly changed the speaking anxiety levels of the teacher candidates in the sub-dimension of "physiological symptoms" and the high speaking anxiety level of female Turkish teacher candidates was attributed to the uncomfortable feeling arising from their exposure to attentive observation of others. Another variable which was found to have no significant impact on the speaking anxiety levels of Turkish teacher candidates was their willingness in their choice of profession. It can be concluded that while the participants may have different reasons for choosing their department of study, they get adapted to the idea of becoming a teacher.

Results of the study revealing that the grade of the students and their public speaking experience significantly change the speaking anxiety levels of Turkish teacher candidates are consistent with similar researches. The study has shown that Turkish teacher candidates studying in the $1^{\text {st }}$ grade have a higher level of speaking anxiety compared to students 
studying in all other grades. Researches conducted by Ozkan and Kinay (2015) and Deringol also emphasized that speaking anxiety levels decreased as the grade of the teacher candidates increased. In view of the Turkish teacher candidates it is considered that, courses included in the curricula such as Oral Expression, Speaking and Effective Communication which intend to the improve the speaking skills of the students both in theory and in practice, help the reduction of the speaking anxiety of the participants as their grade increases. Hasirci (2018) reports that peer communication and teacher feedback have a speaking anxiety-lowering effect on Turkish teacher candidates. When the result of the study concerning the grades is considered along with the research of Hasirci (2018) it can be concluded that, expansion of the social milieu of the participants and the teacher feedbacks on speaking skills particularly in the foregoing courses reduce the speaking anxiety of the research participants.

The results of the study revealing public speaking experience has a significant impact on the speaking anxiety levels of Turkish teacher candidates are consistent with the studies in literature reporting that public speaking experience of teacher candidates has a positive impact on their speaking anxiety. Ozkan and Kinay (2015) report that previous public speaking experience has a speaking anxiety-reducing impact on teacher candidates. In a research conducted by Iscan and Karagoz (2016), Turkish teacher candidates are reported to have a high speaking anxiety, one of the reasons of which is identified to be their lack of public speaking experience. Ozden (2018) argues that Turkish teacher candidates feel inadequate and nervous especially about unprepared speaking. Therefore, allowing Turkish teacher candidates to gain public speaking experience particularly with prepared public speaking scenarios could help the reduction of their speaking anxiety.

\section{References}

Addison, P., Clay, E., Xie, S., Sawyer, C. R., \& Behnke, R. R. (2003). Worry as a function of public speaking state anxiety type. Communication Reports, 16(2), 125-131. https://doi.org/10.1080/08934210309384495

Aktas, S., \& Gunduz, O. (2014). Yazili ve sozlu anlatim. (19. Bask1). Ankara: Akçag.

Baki, Y. (2018). Analysis of speaking self-efficacy and communication skills of prospective Turkish teachers in terms of various variables. Turkish Studies, 13(19), 213-233. https://doi.org/10.7827/TurkishStudies.13949

Daly, J. A., Vangelisti, A. L., \& Lawrence, S. G. (1989). Self-focused attention and public speaking anxiety. Personality and Individual Differences, 10(8), 903-913. https://doi.org/10.1016/0191-8869(89)90025-1

Demir, T., \& Melanlioglu, D. (2014). Speaking anxiety scale for secondary school education students: Validity and reliability study. Ankara University Journal of Faculty of Educational Sciences, 47(1), 103-124.

Deringol, Y. (2018). Speaking anxieties of prospective elementary school teachers. Manisa Celal Bayar Universitesi Sosyal Bilimler Dergisi, 16(3), 23-35.

Dsm, V. (2014). Amerikan Psikiyatri Birligi ruhsal bozuklukların tanisal ve sayimsal el kitabi. (cev. Koroglu, E.). Ankara: HYB.

Forza, C. (2002). Survey research in operations management: a process-based perspective. International Journal of Operations \& Production Management, 22(2), 152-194. https://doi.org/10.1108/01443570210414310

Gunes, F. (2007). Turkce ogretimi ve zihinsel yapilandirma. Ankara: Nobel.

Harris, S. R., Kemmerling, R. L., \& North, M. M. (2002). Brief virtual reality therapy for public speaking anxiety. Cyberpsychology \& Behavior, 5(6), 543-550. https://doi.org/10.1089/109493102321018187

Hasirci, S. (2018). Peer and teacher feedback in terms of effect on speaking anxiety of Turkish teacher candidates. Turkish Studies, 13(4), 685-706. https://doi.org/10.7827/TurkishStudies.13078

Iscan, A., \& Karagoz, B. (2016). A study on speech anxiety of Turkish language teacher candidates (example of Gaziosmanpasa University). Ahi Evran Universitesi Kirsehir Egitim Fakultesi Dergisi (KEFAD), 17(3), 193-206.

Kardas, M. N. (2015). Turkish speaking anxiety of the multilingual Turkish teacher candidates whose second language is Turkish and the relations of the some variables with speaking anxiety. Turkish Studies, 10(7), 541-556.

Katranci, M. (2014). Pre-service teachers' self-efficacy perception of their speaking skills. Bartin University Journal of Faculty of Education, 3(2), 174-195.

Kinay, I., \& Özkan, E. (2014). Developing a scale of speaking anxiety for prospective teachers: The study of validity and reliability. Turkish Studies, 9(5), 1747-1760.

Kuru, O. (2018). Analysis of speech anxiety of classroom teacher candidates. Abant Izzet Baysal Universitesi Egitim Fakultesi Dergisi, 18(4), 2193-2206. https://doi.org/10.17240/aibuefd.2018.18.41844-428575

Kurudayıglu, M. (2014). Konusma egitimi. İstanbul: Kriter. 
MEB (2018). Türkçe dersi ogretim programi. Ankara: MEB.

Ozdemir, E. (2008). Güzel ve etkili konusma sanati. İstanbul: Remzi.

Ozdemir, S. (2018). The effect of prepared speaking on eliminating the speaking anxiety of prospective Turkish teacher. Abant Izzet Baysal Universitesi Egitim Fakultesi Dergisi, 18(1), 361-374.

Ozden, M. (2018). Metaphores developed by Turkish teacher candidates in terms of preparedunprepared speech. Ordu University Journal of Social Science Research, 8(2), 347-357.

Ozkan, E., \& Kinay, I. (2015). Analysing of prospective teachers' speaking anxiety (a sample of Ziya Gökalp Faculty of Education). Uluslararası Turkce Edebiyat Kultur Egitim (TEKE) Dergisi, 4(3), 1290-1301.

Parker, C. (2002). An experiment on public speaking anxiety in response to three different types of virtual audience. Presence, 11(1), 68-78. https://doi.org/10.1162/105474602317343668

Serper, O., Aytac, M., \& Bayram, N. (2013). Ornekleme. (3. Baski). Bursa: Ezgi.

Sever, S, Kaya, Z., \& Aslan, C. (2008). Etkinliklerle Turkce ögretimi. İstanbul: Morpa.

Sevim, O., \& Gedik, M. (2014). The investigation of speech anxiety of secondery school students according to some variables. Ataturk Universitesi Turkiyat Arasttrmalari Enstitusu Dergisi, 52, 379-393.

Seyyar, A. (2007). Insan ve toplum bilimleri terimleri sozlugu. Sakarya: Degisim.

TDK (2011). Turkce sozluk. Ankara: TDK.

Temizyürek, F., Erdem, I., \& Temizkan, M. (2017). Konusma egitimi sözlü anlatim. Ankara: Pegem Akademi. https://doi.org/10.14527/9786053641889

Ucgun, D. (2007). The factors affecting the speaking education. Erciyes Universitesi Sosyal Bilimler Enstitusu Dergisi, $1(22), 59-67$.

\section{Copyrights}

Copyright for this article is retained by the author(s), with first publication rights granted to the journal.

This is an open-access article distributed under the terms and conditions of the Creative Commons Attribution license which permits unrestricted use, distribution, and reproduction in any medium, provided the original work is properly cited. 